University of Nebraska - Lincoln

DigitalCommons@University of Nebraska - Lincoln

Faculty Publications from the Harold W. Manter Laboratory of Parasitology

9-1947

Observations on Some Helminths Parasitic in Ohio Turtles

Robert L. Rausch

University of Washington, rausch@uw.edu

Follow this and additional works at: https://digitalcommons.unl.edu/parasitologyfacpubs

Part of the Parasitology Commons

Rausch, Robert L., "Observations on Some Helminths Parasitic in Ohio Turtles" (1947). Faculty

Publications from the Harold W. Manter Laboratory of Parasitology. 496.

https://digitalcommons.unl.edu/parasitologyfacpubs/496

This Article is brought to you for free and open access by the Parasitology, Harold W. Manter Laboratory of at DigitalCommons@University of Nebraska - Lincoln. It has been accepted for inclusion in Faculty Publications from the Harold W. Manter Laboratory of Parasitology by an authorized administrator of DigitalCommons@University of Nebraska - Lincoln. 


\title{
Observations on Some Helminths Parasitic in Ohio Turtles
}

\author{
Robert Rausch
}

The examination of a number of turtles, collected in Ohio, has disclosed at least thirty-three species of parasitic helminths. Little information is available on the parasites of turtles in the Central States, and it is the purpose of this paper to present data resulting from examinations made on 128 turtles, of seven species.

The distribution of Ohio reptiles was worked out by Conant (1938), and the host names used below are those given by him. Ten species of turtles have been recorded from Ohio. Of these, the Cumberland terrapin, Pseudemys scripta troostii (Holbrook), and the brown soft-shelled turtle, Amyda mutica (Le Sueur), are rare, and local in distribution. In addition to these, we were unable to obtain specimens of the musk turtle, Sternotherus odoratus (Latreille), which, while not common, is rather widely distributed over the State. The seven species of turtles examined were as follows: spiny soft-shelled turtle, Amyda spinifera (Le Sueur); snapping turtle, Chelydra serpentina, (Linné); painted turtle, Chrysemys bellii marginata Agassiz; spotted turtle, Clemmys guttata (Schneider); Blanding's turtle, Emys blandingii (Holbrook); geographic terrapin, Graptemys geographica Le Sueur; and the land turtle Terrapene carolina (Linné). The number of host specimens examined of certain species is not adequate, but since there is no probability that additional specimens will be obtained from this area, the data are presented with these inadequacies. A summary of the results is shown in table 1 .

While we realize that our material cannot be considered sufficient in amount to allow for an ecological study, it seems desirable, nevertheless, to present short descriptions of the major habitats from which the animals were collected. This may be of value to someone doing work of a similar nature in the future. It is hoped that future workers will attempt to correlate distribution of the parasite with the ecology of the host, since little is known of the epidemiology of the helminths parasitic in wildlife.

The locations from which collections were made are indicated by number on the map (Fig. 1.), and descriptions of these habitats are given below.

1. Marion County.-Thirty-four specimens of painted turtle, two of snapping turtle, and two of soft-shelled turtle were collected here. This is flat wet-prairie country, with deep, black soils, and sluggish, mud-bottomed streams. the specimens collected here were taken either from the Little Scioto River and its small tributaries, or from nearby ponds. Numerous turtles were collected by shooting during the months of March and April, just after emergence from hibernation.

2. Union County (south of Marysville).-All the geographic terrapins, two snapping turtles, ten painted turtles, and a single soft-shelled turtle were 
collected in this area. The geographic terrapins were collected from Darby Creek, and the others either from the stream itself, or from nearby ponds. The stream flows through heavily cultivated prairie land.

3. Hardin County (near Mt. Victory).-Eight painted turtles and a single snapping turtle were collected from Cephalanthus bogs common in this area. These small, shallow, woodland ponds are bordered by second-growth timber, and are largely grown up with cat-tails.

4. Wyandot County.-A single specimen of painted turtle was collected in this area. This region does not differ appreciably from the rest of the northern till-plain section.

5. Morrow County (near Sparta).- Two specimens of painted turtle were collected here from a shallow pond. This is rolling, heavily cultivated land.

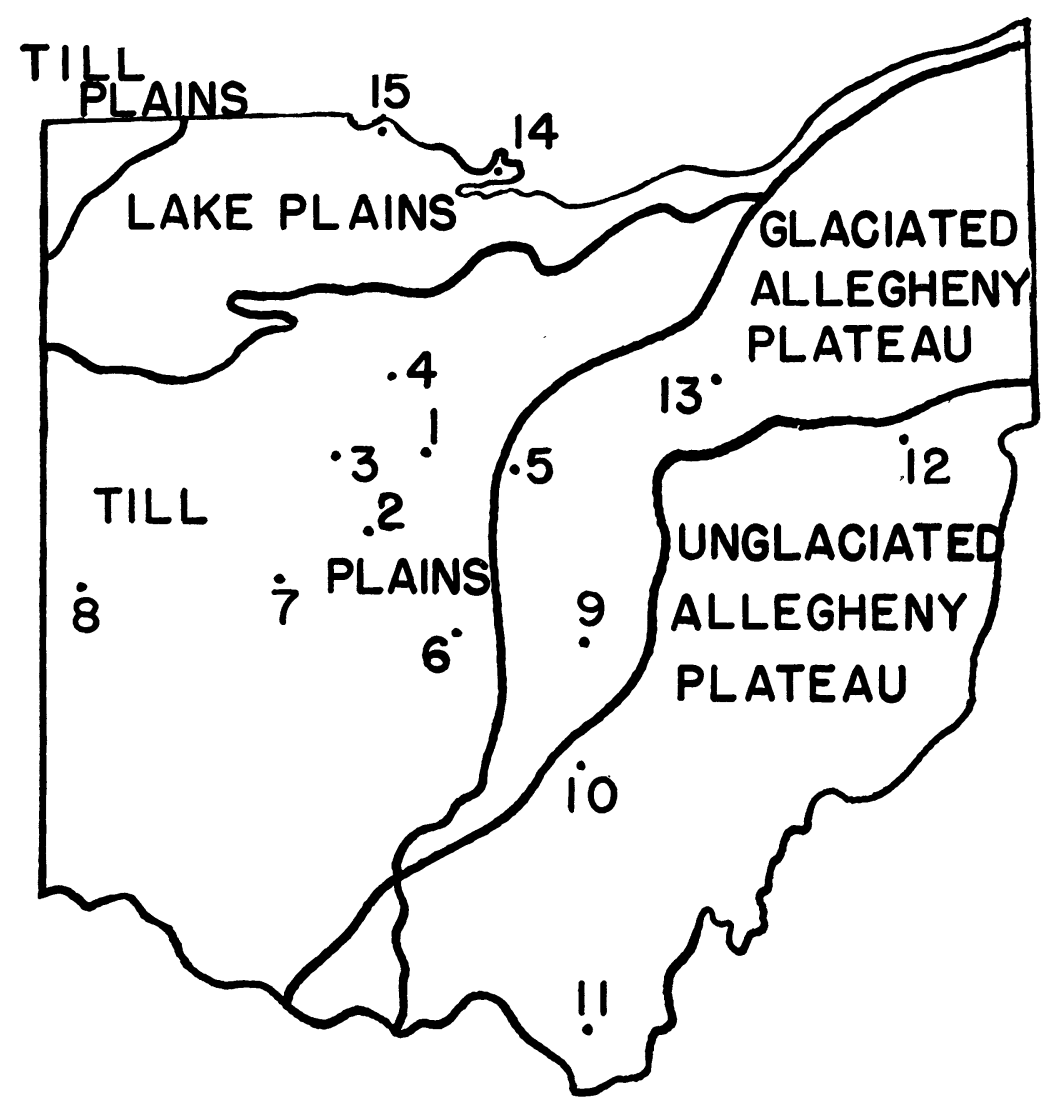

Fig. 1.-Numbers indicate localities from which turtles were collected as given in the text. 
6. Franklin County (near Columbus).-Three painted turtles were collected from Cephalanthus bogs in this area.

7. Champaign County (in Cedar Swamp).-All the spotted turtles examined were collected in this alkaline, spring-fed arbor vitae bog, which is unique in Ohio. A high population of this species of turtle occurs in the clear cold brooks, whose surface supports large patches of watercress.

8. Darke County (near Greenville).-Four large specimens of snapping turtle and five of painted turtle were collected from the long-abandoned gravel pits in this area. These ponds are now used for fish culture.

9. Buckeye Lake.-A single specimen of painted turtle was collected from the reservoir. This species is abundant here, but not easily collected.

10. Hocking County.-Two specimens of land turtle were collected from this region of dry, rocky hills. The soil is sandy, a residue from the massive, coarse-grained Black Hand sandstone, of Mississippian age.

11. Lawrence County.-Fourteen specimens of land turtle were collected here among the dry hills and moist ravines. The soil here is of a sandy composition.

12. Carroll County.-Three specimens of land turtle were collected from this area, which lies in the unglaciated Appalachian Plateau.

13. Wayne County (in Killbuck Marsh).-Two large specimens of snapping turtle were collected here. Cat-tail and three-square bullrush are predominant among a great variety of plants.

14 Ottawa County (near Port Clinton).-Three specimens of painted turtle were collected in the Lake Erie marsh here.

15. Lucas County (on Little Cedar Point).-All the Blanding's turtles were collected in the Lake Erie marsh just off this small peninsula. At times this species is abundant here, depending upon the season, and upon the water level.

Pertinent remarks are given below concerning the helminths encountered. The numbers appearing after the name of the parasite indicate the locality (Fig. 1) where they were collected.

\section{Cestoda}

A single immature cestode (1) was taken from the small intestine of a painted turtle. Identification was not possible. No cestode has previously been recorded from this host, and it is possible that this represents an accidental infection.

\section{Trematoda}

Allosostomoides parvum (Stunkard, 1916) (8).-This trematode was found only twice in the snapping turtle, and infections were light. We re- 
corded one each from the lung and urinary bladder of a small turtle, although the usual habitat is the intestine.

Auridistomum chelydrae (Stafford, 1900) (2, 13).-A single specimen of this trematode was taken from a large snapping turtle collected in Darby Creek, and our notes indicate that it was found in the urinary bladder. The intestine is considered the normal habitat for this parasite. Seven specimens were removed from the intestine of another snapping turtle.

Brachycoelium salamandrae (Froehlich) (11).-Rankin (1945) mentions this species from "land turtles." Twenty-seven specimens were taken from the small intestine of one of the land turtles examined by us, and according to the work of Rankin (1938), these must be assigned to the present species.

Cotylaspis cokeri Barker and Parsons, 1914 (2).-This aspidogastrid was found in the small intestine of the geographic terrapin. Twenty-two specimens were obtained from the three turtles infected. This trematode has been recorded from other turtle species.

Dictyangium chelydrae (Stunkard, 1943) (2).-This parasite, described from the snapping turtle in Louisiana, has not previously been recorded from the geographic terrapin. A total of seven specimens was taken from the small intestines of three turtles.

Heronimus chelydrae MacCallum, 1902 (2, 6, 15).-This widelydistributed trematode was collected only four times. Two Blanding's turtles, a painted turtle, and a snapping turtle were infected. The latter two were collected from woodland ponds, and infection was light in all cases. This was the only lung parasite found by us.

Macravestibulum eversum (Hsü, 1937) (2).-M. eversum waś described from the geographic terrapin in Michigan, and we found it to be the most common trematode infecting this species. As many as 753 specimens of this parasite were taken from the small intestine of a single turtle. Hsü (1937), by means of infection experiments, found that this trematode was either unable to establish itself, or could not reach sexual maturity in other turtle species.

Microphallus opacus (Ward, 1894) $(1,2)$.-This trematode was recorded from the snapping turtle, the painted turtle, and the geographic terrapin. Rausch $(1946,1946 \mathrm{a})$ identified the specimens collected from turtles as Microphallus ovatus Osborn, 1919. Subsequent work, however (Rausch, 1947) has shown $M$. ovatus to be morophologically identical with $M$. opacus.

Neopolystoma orbiculare (Stunkard, 1916) (1).-Polystomes were found only in the painted turtle, and all were in the urinary bladder. There were five mature specimens in the bladder of one turtle, and two others each contained a single immature specimen.

Spirorchis artericola (Ward, 1921) (2).-A single specimen of this blood trematode was taken from the heart of a painted turtle. It is probable that some of the parasites of this genus were overlooked, because of the difficulty in locating them in the circulatory system of the host. 
Published in American Midland Naturalist (September 1947) 38(2): 434-442.

Copyright 1947, the University of Notre Dame. Used by permission.

TABLE 1. Summary of Results

\begin{tabular}{cccc} 
Host & $\begin{array}{c}\text { No. ex - } \\
\text { amined }\end{array}$ & Parasite & $\begin{array}{c}\text { No. in- } \\
\text { fected }\end{array}$ \\
\hline \hline Amyda spinifera (Le Sueur) & ............ 3 & Spiroxys contortus & 1
\end{tabular}

Chelydra serpentina (Linné)

11

Chrysemys bellii marginata Agassiz ..67

Clemmys guttata (Schneider) 8

Emys blandingii 3

Graptemys geographica (Le Sueur) ..17

Terrapene carolina (Linné) 19
Spiroxys contortus .-

Aplectana sp. ........................................ 2

Camallanus microcephalus ................. 1

Eustrongylides sp. ................................ 2

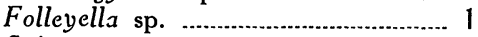

Spiroxys contortus ................................. 2

Allosostomoides parvum ...................... 2

Auridistomum chelydrae ...................... 3

Heronimus chelydrae ........................ 2

Microphallus opacus ............................. 1

Spirorchis haematobium ...................... 2

Telorchis attenuatus ........................... 1

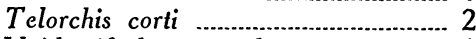

Unidentified trematode ......................... 1

Camallanus microcephalus .................36

Physaloptera sp. .............................. 1

Spiroxys constricta ............................... 4

Spiroxys contortus ............................ 6

Neoechinorhynchus emydis ................. 2

Heronimus chelydrae ........................ 1

Microphallus opacus ............................ 2

Neopolystoma orbiculare ................... 3

Spirorchis artericola .......................... 1

Spirorchis parvum .............................. 1

Telorchis attenuatus ................................ 8

Telorchis corti .................................... 6

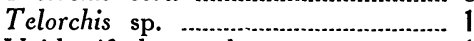

Unidentified cestode ............................ 1

Spironoura affine ............................... 4

Telorchis robustus .............................. 4

Aplectana sp. ................................... 1

Camallanus microcephalus ................. 1

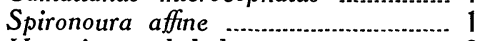

Heronimus chelydrae ......................... 2

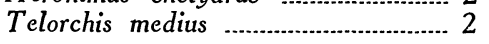

Camallanus microcephalus ................. 2

Spironoura affine ............................. 4

Spironoura concinnae ......................... 1

Spironoura wardi ................................. 2

Spiroxys constricta ............................ 1

Neoechinorhynchus emydis ................ 14

Cotylaspis coleri ............................. 3

Dictyangium chelydrae ...................... 3

Macravestibulum eversum ................. 9

Microphallus opacus ........................... 4

Spirorchis innominata ....................... 1

Telorchis corti .................................... 8

Aplectana sp. ............................. 1

Cosmocercoides dukae ...................... 1

Oswaldocruzia sp. prob. leidyi .........10

Spironoura affine ......................... 9

Brachycoelium salamandrae ............... 1

Telorchis sp. ................................. 1 
Spirorchis haematobium (Stunkard, 1922) (2, 3).-This species was found twice in snapping turtles. One turtle was captured in a Cephalanthus bog, and the other in Darby Creek. There were eleven and four trematodes, respectively. All were found in the heart.

Spirorchis innominata Ward, 1921 (2).-A single specimen was removed from the heart of a geographic terrapin.

Spirorchis parvum (Stunkard, 1923) (8).-A single specimen was removed from the circulatory system of a painted turtle.

Telorchis attenuatus Goldberger, $1911(1,2,5,8)$.- This was the common species of Telorchis in the painted turtle, and it was also found once in a snapping turtle. Most of the turtles harboring this parasite were collected from ponds. Ten was the maximum number of $T$. attenuatus taken from a single turtle; usually, however, only one or two were present.

Telorchis corti Stunkard, 1915 (1, 2, 8).-This trematode was commonly found in the geographic terrapin and in the snapping turtle, although a few were also found in the painted turtle. As many as fifty-one specimens of this trematode were taken from a single turtle, and infections averaged much larger than with the preceding species.

Telorchis medius Stunkard, 1915 (15).-Abundant in the small intestine of Blanding's turtle, with as many as seventy-one specimens in a single host.

Telorchis robustus Goldberger, 1911 (7).-Found only in the spotted turtle, in the small intestine. The largest number found in a single host was four, with an average of about two.

Telorchis spp. (11).-A single specimen of Telorchis sp. was taken from the small intestine of a land turtle. This could not be assigned to any of the existing North American species, and appears to be near T. stossichi Goldberger, 1911. Two specimens from the painted turtle likewise cound not be identified to species. These were peculiar in having the ovary lying near the anterior testis. Additional specimens will be necessary to complete these identifications.

Unidentified trematodes (13).-Three specimens of a very small immature trematode were removed from the gall bladder of a large snapping turtle. These stained poorly and could not be identified.

\section{Nematoda}

Aplectana sp. $(8,12,13,15)$.-Larval aplectanids were removed from the lower intestine of the land turtie, snapping turtle, and Blanding's turtle. Infections in all cases were light.

Camallanus microcephalus (Duj. 1845) $(1,2,3,6,8,13,14,15)$.-This was the most common nematode found. It occurred in Blanding's turtle, painted turtle, snapping turtle, and geographic terrapin. It was common only in the painted turtle, however, and it occured in large numbers in this species 
only. These nematodes were found tightly attached to the duodenal wall just below the pyloric valve.

Cosmocercoides dukae (Holl, 1928) (12).-Found once in the large intestine of a land turtle. It has previously been recorded from numerous species of cold-blooded vertebrates, including the land turtle. Most of the previous hosts have been terrestrial forms.

Eustrongylides sp. (8).-Immature specimens of this nematode were found once beneath the peritoneum in the rectal region of a snapping turtle.

Foleyella sp. (8).-Immature specimens of this filariid also occurred beneath the peritoneum in the body cavity of the snapping turtle.

Oswaldocruzia sp., probably O. leidyi $(10,11,12)$.- This nematode was found commonly in the stomach of the land turtle. It has been recorded from several other terrestrial cold-blooded vertebrates. These occurred in small numbers in the turtles examined by us.

Physaloptera sp. (1).-Two specimens of nematodes belonging to this genus were taken from the stomach of a painted turtle.

Spironoura affine Leidy, $1856(2,7,11,15)$. - This was the common nematode, infecting the spotted turtle, although the number found in a single host was small. It also occurred commonly in the land turtle, geographic terrapin, and Blanding's turtle.

Spironoura concinnae Makin, 1936 (2).-This nematode was found in the intestine of a single specimen of the geographic terrapin.

Spironoura wardi Makin, 1936 (2).- This nematode occurred in the large intestine of the geographic terrapin.

Spiroxys constricta (Leidy, 1856) (12).-The painted turtle was the only species from which this nematode was taken, and the habitat was the stomach. A few were also taken from the lower intestine, where they possibly had migrated after the death of the turtle.

Spiroxys contortus (Rud. 1819) (1, 2, 5, 13).- This nematode was abundant in the stomach of one of the soft-shelled turtles. The turtle was not examined immediately, after having been collected by shooting, and these nematodes began to emerge through its mouth. This was also a common parasite in the stomach of the painted turtle, and it occurred less commonly in the geographic terrapin and snapping turtle.

\section{ACANTHOCEPHALA}

Neoechinorhynchus emydis (Leidy, 1852) (2, 5).- This spiny-headed worm was common in the geographic terrapin and was recorded twice from the painted turtle. The former seems to be a more suitable host, compared with painted turtles collected from the same habitat. Except for a single painted turtle taken from a pond, all the infected turtles were collected from a stream. The painted turtles infected each contained a single worm, while infections 
of from two hundred to three hundred of these parasites were not uncommon among the geographic terrapins.

A benign neoplasm was present on the small intestine of one of the geographic terrapins, and this appeared to have resulted from infection with $N$. emydis. According to our notes, the mucosa was reddened, and the intestinal wall was greatly thickened into a mass about three centimeters in diameter. The tumor was hollow, and filled with a caseous, brown mass, in which were imbedded several specimens of $N$. emydis. A section, with trichrome staining, showed marked proliferation of connective tissue in the intestinal wall. Considerable eosinophilic infiltration was noted, with very little leukocytic barrier. Wieczorowski (1939) has made some observations on parasitic lesions in turtles.

\section{Miscellaneous Conditions}

A painted turtle, collected from a large pond near Marion, showed numerous calcarious bodies imbedded along the wall of the small intestine. These measured up to five or six millimeters in diameter, and were probably parasitic in origin. Numerous eosinophiles had invaded the area. A second painted turtle, collected at the same locality, showed a dry necrosis of all four feet. The necrosis progressed for the most part under the skin. The smaller bones of the pelvic limbs had sloughed off, leaving the ends of the tibiae exposed. The cause for this could not be determined. The stomach of a large soft-shelled turtle showed numerous nodules, some of which were pedunculated, on the serosa. These nodules showed a tubercle-like formation, with giant cells present. Extremely large numbers of eosinophiles had invaded the tissue surrounding these areas.

As far as we were able to determine, there was no seasonal variation in the degree of parasitism of the turtles examined. Turtles collected just after emergence from hibernation were apparently as heavily parasitized as those collected later in the year. It was noted, however, that young turtles, regardless of species, were infected with fewer parasites, and that the degree of parasitism appeared to increase with the age of the host. This possibly indicates a gradual accumulation of parasites over a period of time, rather than exposure to infection resulting from a change in feeding habits.

\section{ACKNOWLEDGMENTS}

We wish to express indebtedness to Dr. A. C. Walton for the identification of most of the nematodes, and to Dr. H. J. Van Cleave for the identification of the acanthocephala. Turtles were supplied by several individuals, and we wish to take this opportunity to thank them for their cooperation. In this respect we are especially indebted to Dr. L. E. Hicks, Dr. C. A. Dambach, Mr. George Breiding, Dr. W. H. Wilson, Mr. L. H. Troesch, Mr. Carl Troesch, and Mr. Merrill Gilfillan.

\section{REFERENCES}

Conant, R. 1938 - The reptiles of Ohio. Amer. Midl. Nat. 20:1-200.

Hsü, D. 1937-Life history and morphology of Macravestibulum eversum sp. nov. (Pronocephalidae, Trematoda). Trans. Amer. Micr. Soc. 56:478-504. 
Published in American Midland Naturalist (September 1947) 38(2): 434-442.

Copyright 1947, the University of Notre Dame. Used by permission.

RANkin, J. S. 1938-Studies on the trematode genus Brachycoelium Duj. I. Variation in specific characters with reference to the validity of the described species. Ibid. $57: 358-375$.

1945-An ecological study of the helminth parasites of amphibians and reptiles of western Massachusetts and vicinity. J. Parasitol. 31:142-150.

RaUsch, R. 1946-New host records for Microphallus ovatus Osborn, 1919. Ibid. $32: 93-94$.

1946a-The raccoon a new host for Microphallus sp. with additional notes on M. ovatus from turtles. Ibid. $32: 208-209$.

1947-Some observations on the host relationships of Microphallus opacus (Ward, 1894). Trans. Amer. Micr. Soc. 66:59-63.

WIEczorowski, E. 1939_Parasitic lesions in turtles. J. Parasitol. 25:395-399.

DEPARTMENT OF VETERINARY SCIENCE

UNIVERSITY OF WISCONSIN.

Formerly of Ohio Cooperative Wildlife Research Unit

Ohio State University

Columbus, Ohio. 